\title{
Development of polymerase chain reaction assays for detection, identification, and differentiation of Piscirickettsia salmonis
}

\author{
M. J. Mauel, S. J. Giovannoni, J. L. Fryer * \\ Department of Microbiology and Center for Salmon Disease Research, Nash Hall 220, Oregon State University, Corvallis, \\ Oregon 97331-3804, USA
}

\begin{abstract}
A nested polymerase chain reaction (PCR) was developed to detect genomic DNA of Piscirickettsia salmonis, the causative agent of an epizootic disease in salmonids. The nested PCR assay, which used general bacterial $16 \mathrm{~S}$ rDNA primers in the first amplification reaction, and $P$. salmonisspecific primers in a second reaction, allowed detection of less than $1 P$. salmonis tissue culture infectious dose $50\left(\mathrm{TCID}_{50}\right)$. Using the $P$. salmonis-specific primers in a single PCR reaction allowed the detection of 60 TCID $_{50}$. The specificity of the PCR was assessed with a panel of 4 salmonid and 15 bacterial genomic DNA preparations. Amplification products were produced only with $P$. salmonis DNA Restriction fragment length polymorphism (RFLP) analysis of the complete 165 gene PCR products demonstrated that 1 isolate, EM-90, was unique. Two additional primers were developed and used in PCR assays that differentiated EM-90 from the 4 other $P$. salmonis isolates tested
\end{abstract}

KEY WORDS: Piscirickettsia salmonis $\cdot$ DNA $\cdot$ PCR $\cdot$ Fish disease $\cdot$ Salmonid $\cdot$ Rickettseae

\section{INTRODUCTION}

Salmonid mariculture in Chile has undergone rapid growth and development during the last 2 decades. In the late 1980 s a number of mariculture facilities began experiencing extensive losses due to an infectious disease of unknown etiology. Signs of the disease became evident 6 to $8 \mathrm{wk}$ after fish were moved to salt water netpens. In 1989 mortality up to $90 \%$ was reported in some coho salmon Oncorhynchus kisutch facilities in the Puerto Montt area of southern Chile (Bravo \& Campos 1989). The etiologic bacterium of this disease was isolated (Fryer et al. 1990) and characterized (Fryer et al. 1992). The causative agent was designated Piscirickettsia salmonis (gen. nova, sp. nova), an intracellular parasite and the first such rickettsial-like agent isolated from fish. The disease was designated piscirickettsiosis. Since $P$. salmonis first appearance in Chile, Piscirickettsia or Piscirickettsia-like organisms

\footnotetext{
•Addressee for correspondence.E-mail: fryerj@bcc.orst.edu
}

have been reported from salmonids in Canada (Evelyn 1992), Norway (Olsen et al. 1993! and Ireland (Rodger \& Drinan 1993).

Presumptive diagnoses of piscirickettsiosis are made by observing gross signs of disease, histological staining of smears or tissue sections, electron microscopy, isolation in fish cell cultures and consideration of the previous disease history in the rearing facility. Currently, confirmation of Piscirickettsia salmonis is accomplished by indirect fluorescent antibody test (IFAT; Lannan et al. 1991j. While the IFAT is invaluable, it uses polyclonal antibodies that do not differentiate between isolates of $P$. salmonis. Electron microscopy is time consuming and expensive, and organisms of similar morphology are difficult to differentiate. $P$. salmonis is sensitive to many of the antibiotics commonly used in cell culture media, making isolation of the agent from tissues of infected fish difficult and time consuming due to contamination. The problems associated with the above diagnostic methods demonstrate the need for a highly specific, sensitive and rapid assay for diagnosis of piscirickettsiosis. 
In addition to the isolates from salmonids, rickettsialike organisms have recently been isolated or reported from several species of tilapia (Oreochromis and Tilapia sp.) in Taiwan (Chern \& Chao 1994) and Japan (Wada et al. 1995). Other rickettsia-like organisms have been reported in the blue-eyed plecostomus Panaque suttoni from Colombia, South America (Khoo et al, 1995) and juvenile sea-bass Dicentrarchus labrax in France (Comps 1996). The discovery of these agents demonstrates the need for a highly specific, sensitive assay which can differentiate Piscirickettsia salmonis from other rickettsia-like agents.

This report describes the development of a nested polymerase chain reaction (PCR) for detecting Piscirickettsia salmonis genomic DNA from cultured fish ceils and the tissues of intected tish. This assay proved to be both specific and sensitive. Two additional PCR primers were developed that differentiated between $P$. salmonis isolate EM-90 and the other 4 isolates of $P$. salmonis examined in this study.

\section{MATERIAL AND METHODS}

Bacterial strains and culture. The species examined, their strain designations and isolation sources are listed in Table 1. The bacterium Neorickettsia helminthoeca was obtained along with the metacercariae of its host Nanophyetus salmincola from kidney tissue of adult steelhead trout Oncorhynchus mykiss (Gebhard et al. 1966). No attempt was made to isolate the bacterium from the metacercariae.
Piscirickettsia isolates were grown at $15^{\circ} \mathrm{C}$ in chinook salmon embryo cell line (CHSE 214, Lannan et al. 1984) in antibiotic-free Eagle's minimum essential medium (MEM) with Earle's salts (Sigma Chemical Co., St. Louis, MO, USA) supplemented with $10 \%$ fetal bovine serum (Hyclone Laboratories, Inc., Logan, UT, USA) until lysis of the cell sheet was near completion (approximately $14 \mathrm{~d}$ ).

DNA isolation. Piscirickettsia salmonis DNA was isolated using DNA-STAT 60 (Tel-Tex, Inc., Friendswood, TX, USA) following the manufacturer's protocol. Briefly, $7 \mathrm{ml}$ of DNA-STAT 60 was added to $25 \mathrm{~cm}^{2} \mathrm{cul}-$ tures near complete lysis and the cells and supernatant passed through a pipette 5 times to disrupt the remaining intact CHSE 214 cells and lyse the bacterial cells. Next, $1.5 \mathrm{mi}$ of chloroform was added, the mixture was shaken for $30 \mathrm{~s}$ and then centrifuged at $16000 \times \mathrm{g}$ for $15 \mathrm{~min}$ at $4^{\circ} \mathrm{C}$ in a microcentrifuge. The upper layer was transferred to a second tube and DNA precipitated with $500 \mu \mathrm{l}$ of $100 \%$ isopropanol. After $10 \mathrm{~min}$ at room temperature the DNA was pelleted by centrifugation at $16000 \times \mathrm{g}$ at $4^{\circ} \mathrm{C}$ for $10 \mathrm{~min}$ in a microcentrifuge. The supernatant was then removed, the pellet vacuum dried for $10 \mathrm{~min}$ and resuspended in $200 \mathrm{\mu l}$ TE (100 mM Tris pH 8.0,10 mM EDTA).

The Norwegian isolate, NOR-92, was contaminated with a mycoplasma. To overcome this, amplification was performed on a plasmid (pCRI ${ }^{\oplus}$, Invitrogen, San Diego, CA, USA) that contained the NOR-92 16 S gene as an insert. Due to limited DNA availability, isolates LF-89 and EM-90 were also amplified from plasmid inserts.

Table 1. Bacteria examined in this study

\begin{tabular}{lll|}
\hline Species $^{\text {a }}$ & Strain designation & Original isolation source \\
\hline Piscirickettsia salmonis & LF-89 ATCC VR 1361 & Coho salmon Oncorhynchus kisutch \\
& EM-90 & Atlantic salmon Salmo salar \\
& SLGO-94 & Rainbow trout Oncorhynchus mykiss \\
ATL-4-91 & Atlantic salmon S. salar \\
Vibrio anguillarum type 1 & NOR-92 & Atlantic salmon S. salar \\
Pseudomonas fluorescens & LS174 & Chinook salmon Oncorhynchus tshawytscha \\
Edwardsiella tarda & $4-13-78$ & Unknown \\
Edwardsiella ictaluri & ATCC 15948 & Human \\
Pasteurella piscicida & ATCC 33202 & Channel catfish Ictalurus punctatus \\
Carnobacterium piscicola & $7-1-77$ & Unknown \\
Lactococcus lactis & LBK1-70 & Rainbow trout O. mykiss \\
Aeromonas hydrophila & ATCC 19435 & Unknown \\
Aeromonas salmonicida & ATCC 14715 & Coho salmon O. kisutch \\
Yersinia ruckerii & ATCC 33685 & Atlantic salmon S. salar \\
Staphylococcus aureus & HI-70 & Rainbow trout O. mykiss \\
Renibacterium salmoninarum & ATCC 35548 & Unknown \\
Flexibacter psychrophilus & D6 & Coho salmon O. kisutch \\
Escherichia coli & SR1-77 & Coho salmon O. kisutch \\
Lactococcus piscicum & ATCC 33430 & Human \\
all non P. salmonis species were provided by the Oregon State University Department of Microbiology Fish Pathogen & \\
Culture Collection & $7-77$ & Coho salmon O. kisutch \\
& &
\end{tabular}


Chromosomal DNA from each of the non-Piscirickettsia salmonis bacterial strains was prepared as above using DNA-STAT 60 with the following modifications: $5 \mathrm{ml}$ Lennix L broth cultures were incubated, with shaking, at either 16 or $37^{\circ} \mathrm{C}$ i the bacterial cells were pelleted and resuspended in $1.5 \mathrm{ml}$ DNA-STAT 60; $300 \mu$ l of chloroform was added. DNA from rainbow trout Oncorhynchus mykiss, chinook Oncorhynchus tshawytscha, coho, and Atlantic salmon Salmo salar were provided by J. Leong (Dept. of Microbiology, Oregon State University, Corvallis, OR, USA). As a confirmation of the quality of the bacterial DNA, 16S genes were amplified prior to performing the nested PCR (data not shown).

Infected coho salmon kidney and spleen tissues fixed in ethanol were provided by P. Smith (Veterinary Sciences, University of Chile, Santiago, Chile) from a culture facility in Chile that was experiencing an epizootic of piscirickettsiosis. Piscirickettsia salmonis infection was confirmed by observation and histological staining for the presence of rickettsia-like organisms in host cells. Healthy coho salmon tissues obtained from the Oregon Department of Fish and Wildlife, Fall Creek Hatchery, Alsea, OR, USA, served as negative controls, since there is no history of $P$. salmonis in Oregon.

Fish infected with Nanophyetus salmincola, the host of Neorickettsia helminthoeca, were obtained from a location where the salmon poisoning syndrome is endemic (Gebhard et al. 1966). The genomic DNA of $N$. helminthoeca, its host $N$. salmincola and the $N$. salmincola fish host, steelhead trout, were isolated together from kidney tissue using DNA-STAT 60 as previously described. DNA was also isolated from infected tissue by concentration of the $N$. salmincola metacercariae as follows: $1 \mathrm{~g}$ of infected steelhead kidney tissue was homogenized in $50 \mathrm{ml}$ phosphatebuffered saline (PBS), the metacercariae were allowed to settle for $4 \mathrm{~h}$ (Gebhard et al. 1966), the supernatant removed and the DNA extracted with DNA-STAT 60. The number of metacercariae per gram of host tissue was determined by counting in a haemocytometer. Staining with Giemsa was used to establish the presence of rickettsia-like bodies in the metacercaria.
Salmonid kidney or spleen tissues (100 mg), negative control or Piscirickettsia salmonis infected, were digested for $3 \mathrm{~h}$ at $65^{\circ} \mathrm{C}$ in $250 \mu \mathrm{l}$ of lysis buffer $(50 \mathrm{mM}$ $\mathrm{KCl}, 10 \mathrm{mM}$ Tris pH $7.8,2.5 \mathrm{mM} \mathrm{MgCl}, 0.1 \%$ gelatin, $0.45 \%$ NP40, $0.45 \%$ Tween 20 with $1 \mathrm{mg} \mathrm{ml}^{-1}$ proteinase $K$ added just before use), followed by boiling for $10 \mathrm{~min}$, quenching on ice and centrifugation to remove cell debris. Of the supernatant, $5 \mu$ l was used for PCR.

Oligonucleotide design and synthesis. The Piscirickettsia-specific primers (Table 2 ) were designed by comparing the published sequence (Fryer et al. 1992, EMBL accession no. X60783) and 20 other published bacterial sequences using the Genetic Data Environment (GDE version 2.2) software package. The proposed primers were further tested for specificity using a commercially available software package (Amplify; University of Wisconsin, Madison, WI, USA) and the Ribosomal Data Base project program Check Probe (Maidak et al. 1994). From 16S rDNA sequence data of 5 P. salmonis isolates (GenBank accession numbers: LF-89 U36941, EM-90 U36940, ATL-4-91 U36915, NOR-92 U36942, SLGO-94 U55015) 2 additional primers, PS3AS and EM90AS, were developed (Table 2). The design of the universal primers EubA and EubB has been described (Giovannoni 1991). The oligonucleotides were synthesized at the Oregon State University Center for Gene Research and Biotechnology Central Services facility.

PCR amplification and Restriction Fragment Length Polymorphism (RFLP). In the first amplification of the nested PCR, $5 \mu$ l of DNA lysate was added to $45 \mu \mathrm{l}$ of reaction mixture consisting of $1 \times \mathrm{PCR}$ buffer (Promega, Madison, WI, USA; $10 \mathrm{mM}$ Tris $\mathrm{HCl}(\mathrm{pH} 9.0)$, $1.5 \mathrm{mM} \mathrm{MgCl}, 50 \mathrm{mM} \mathrm{KCl}, 0.1 \%$ Triton $\times 100$ ), $200 \mu \mathrm{M}$ each of dATP, dCTP, dTTP and dGTP, $1 \mu \mathrm{M}$ EubA primer, $1 \mu \mathrm{M}$ EubB primer and $2.5 \mathrm{U}$ Taq DNA polymerase (Promega), and covered with $50 \mu$ l of mineral oil. The mixture was denatured at $94^{\circ} \mathrm{C}$ for 2 min and amplification was performed with 35 cycles of $94^{\circ} \mathrm{C}$ for $1 \mathrm{~min}, 50^{\circ} \mathrm{C}$ for $2 \mathrm{~min}$, and $72^{\circ} \mathrm{C}$ for $3 \mathrm{~min}$. The tubes were then held at $4^{\circ} \mathrm{C}$.

The second amplification was performed by adding $3 \mu \mathrm{l}$ of the first PCR products to the reaction mixture containing $2 \mu \mathrm{M}$ each of PS2S and PS2AS primers in-

Table 2. Sequences and specificity of primers utilized for the identification or differentiation of Piscirickettsia salmonis strains

\begin{tabular}{|c|c|c|}
\hline Primer (Location ${ }^{a}$ ) & Sequence $\left(5^{\prime}-3^{\prime}\right)$ & Specificity \\
\hline EubB (27F) & AGAGTTTGATCMTGGCTCAG & Eubacterial \\
\hline PS2S $(223 F)$ & CTAGGAGATGAGCCCGCGTTG & P. salmonis (all strains) \\
\hline PS2A2 (690R) & GCTACACCTGCGAAACCACTT & P. salmonis (all strains) \\
\hline PS3AS (1032R) & TCCCGAAGGCACTTCCGCATCTC & P. salmonis (LF-89 type strain) \\
\hline EM90AS (1032R) & TCCCGAAGGCACATCAATATCTCTATC & P. salmonis (EM-90) \\
\hline EubA (1518R) & AAGGAGGTGATCCANCCRCA & Eubacterial \\
\hline
\end{tabular}


stead of the EubA and EubB primers. Reaction conditions were: 35 cycles of $94^{\circ} \mathrm{C}$ for $1 \mathrm{~min}, 61^{\circ} \mathrm{C}$ for $2 \mathrm{~min}$, and $72^{\circ} \mathrm{C}$ for $3 \mathrm{~min}$. Alternatively, amplifications with the primer sets PS2S-PS3AS or PS2S-EM90AS were performed by adding $2 \mu \mathrm{M}$ of each primer to the above reaction mixture. The reaction conditions were modified as follows: 35 cycles of $94^{\circ} \mathrm{C}$ for $1 \mathrm{~min}, 65^{\circ} \mathrm{C}$ for $2 \mathrm{~min}$, and $72^{\circ} \mathrm{C}$ for $3 \mathrm{~min}$. Amplifications from plasmid DNA were achieved with the same reaction conditions as the genomic DNA. Aliquots $(10 \mu \mathrm{l})$ of the PCR reaction mixture were electrophoresed in $2 \%$ agarose $1 \times$ TAE (40 mM Tris acetate/1 mM EDTA) gel containing $1 \mathrm{mg}$ per $50 \mathrm{ml}$ ethidium bromide and photographed under UV transillumination. Aliquots $(10 \mu \mathrm{l})$ of the PCR reaction products were digested with EcoRI or PstI (Fromega) foliowing the manutacturers instructions and visualized as described.

PCR sensitivity. To define the sensitivity of the PCR assay Piscirickettsia salmonis DNA was serially diluted and $6 \times 10^{7}$ tissue culture infectious dose $50\left(\mathrm{TCID}_{50}\right)$ to $0.6 \mathrm{TCID}_{50}$ of DNA was added to the reaction mixture. The $P$. salmonis cells were stained with Giemsa and counted with a haemocytometer for comparison with the TCID ${ }^{50}$ counts.

\section{RESULTS}

\section{Development of the PCR}

Amplification of Piscirickettsia salmonis genomic DNA with primers PS2S and PS2AS resulted in a product with the predicted 476 bp length (Fig. 1A). Verification that the product was from the $16 \mathrm{~S}$ gene of $P$. salmonis was determined by sequencing the LF-89 PCR product and aligning it to the $P$. salmonis LF-89 sequence (Fryer et al 1992, EMBL accession no. X60783). Amplification using PS2S and either PS3AS or EM90AS resulted in the appearance of the predicted 816 bp PCR products (Fig. 2).

\section{Detection threshold of the PCR}

Amplification of 10 -fold serial dilution's of Piscirickettsia salmonis DNA indicated that less than $1 \mathrm{TCID}_{50}$ could be detected in a $2 \%$ agarose gel with the nested PCR (Fig. 3A). However, for reasons that remain unclear, amplification of the 467 -bp product from $6 \times$ $10^{4} \mathrm{TCID}_{50}$ was consistently less than that obtained from $6 \times 10^{3}$ TCID $_{50}$ or less (Fig. 3A). When using DNA isolated from infected fish cell cultures or purified $P$. salmonis (Lannan et al. 1991), a single amplification step with the PS2S and PS2AS primers was sufficient to detect the P. salmonis $16 \mathrm{~S}$ gene at 60 TCID $_{50}$ (Fig. 3B).
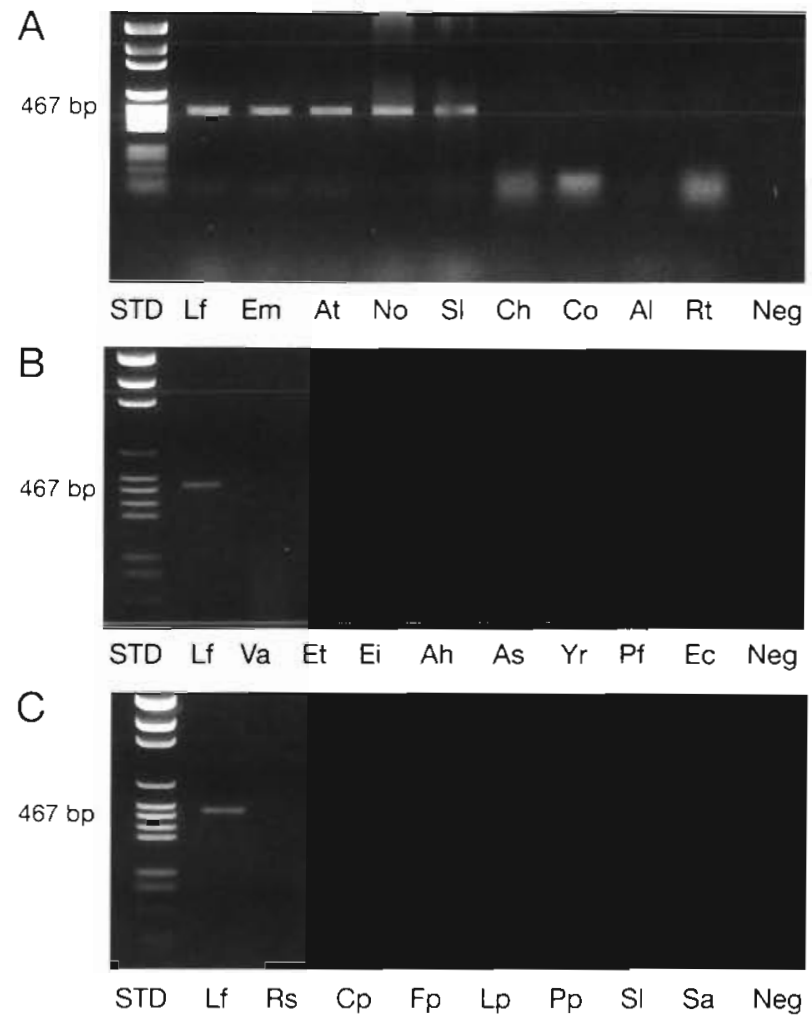

Fig. 1 Specificity of Piscirickettsia salmonis PCR using DNA from various bacterial and salmonid DNAs. STD = pGEM DNA standard (Promega). Neg = no DNA negative control. $\mathrm{Lf}=P$. salmonis isolate LF-89, used as a positive control in gels $B$ and C. (A) P. salmonis isolates: $\mathrm{Lf}=\mathrm{LF}-89, \mathrm{Em}=\mathrm{EM}-90$, At $=$ ATL-4-91, No $=$ NOR-92, $\mathrm{Sl}=\mathrm{SLGO}-94, \mathrm{Ch}=$ chinook salmon Oncorhynchus tshawytscha, $\mathrm{Co}=$ coho salmon Oncorhynchus kisutch, $\mathrm{Al}=$ Atlantic salmon Salmo salar, $\mathrm{Rt}=$ rainbow trout Oncorhynchus mykiss. (B) Va = Vibrio anguillarum type 1, $\mathrm{Et}=$ Edwardsiella tarda, $\mathrm{Ei}=$ Edwardsiella ichtaluri, Ah $=$ Aeromonas hydrophila, $\mathrm{As}=$ Aeromonas salmonicida, $\mathrm{Yr}=$ Yersinia ruckerii, $\mathrm{Pf}=$ Pseudomonas fluorescens, $\mathrm{EC}=$ Escherichia coli. $(\mathrm{C}) \mathrm{Rs}=$ Renibacterium salmoninarum, $\mathrm{Cp}=$ Carnobacterium piscicola, $\mathrm{Fp}=$ Flexibacter psychrophilus, $\mathrm{Lp}=$ Lactococcus piscicum, $\mathrm{Pp}=$ Pasteurella piscicida,

$\mathrm{Ll}=$ Lactococcus lactis, $\mathrm{Sa}=$ Staphylococcus aureus

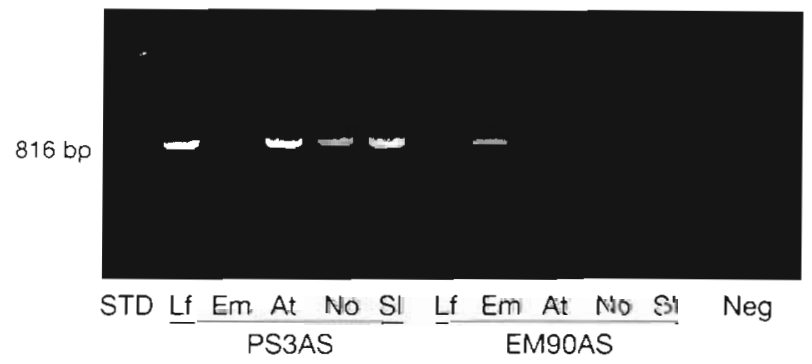

Fig. 2. Differentiation of Piscirickettsia salmonis isolates by PCR. Both assays produce an 816 bp product. Isolates: Lf $=$ LF-89, Em = EM-90, At = ATL-4-91, No = NOR-92, Sl = SLGO 94. PS3AS indicates amplification using the primer pair PS2SPS3AS. EM90AS indicates amplification using the primer pair PS2S-EM90AS. STD = pGEM DNA markers. Neg = no DNA negative control 

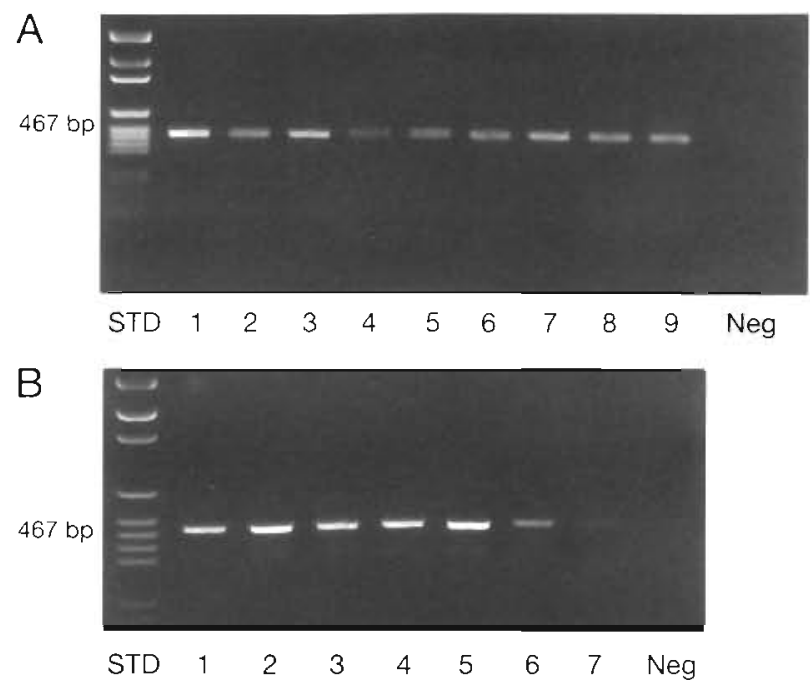

Fig. 3. Detection thresholds of the nested (A) (EubA-EubB primer pair first round, PS2S-PS2AS primer pair second round) and single round PCRs and (B) (PS2S-PS2AS primer pair) PCRs. Each lane represents the equivalent DNA, in each $50 \mu \mathrm{l}$ PCR, from the following number of tissue culture infectious dose $50\left(\mathrm{TCID}_{50}\right):$ (1) $6 \times 10^{7} \mathrm{TCID}_{50 .}$ (2) $6 \times 10^{\mathrm{h}} \mathrm{TClD}_{501}$, (3) $6 \times$ $10^{5} \mathrm{TCID}_{50,}(4) 6 \times 10^{4} \mathrm{TCID}_{50}$ (5) $6 \times 10^{3} \mathrm{TCID}_{50}$ (6) 600 TCID 50 . (7) $60 \mathrm{TCID}_{5 ! 1}$ (8) $6 \mathrm{TCID}_{50}$ (9) $0.6 \mathrm{TCID}_{50}$. STD = pGEM DNA markers (Promega). Neg = no DNA negative control

Performing 2 sequential amplifications using the species-specific primers PS2S and PS2AS produced variable yield and was not consistently observed in agarose gels (data not shown).

\section{Restriction Fragment Length Polymorphism (RFLP)}

All 5 isolates produced a product of approximately 1540 bp when amplified with the universal primers EubA and EubB. When these products were cut with EcuRI LF-89, ATL-4-91, NOR-92 and SLGO-94, all produced 2 bands ( 994 bp and 546 bp). EM-90 was not cut by the restriction endonuclease EcoRI. The restriction endonuclease $P_{S t}$ I produced 3 bands (541 bp, $519 \mathrm{bp}$, and $480 \mathrm{bp}$ ) from the $16 \mathrm{~S}$ PCR products of isolates LF-89, ATL4-91, NOR-92 and SLGO-94 and 2 bands (1058 bp and 482 bp) from EM-90 (Fig. 4). The use of RFLP demonstrated that E: $M-90$ was distinguishable from the other 4 isolates of Piscirickettsia salmonis.

\section{Specificity of the PCR}

When using the primer combination of PS2S and PS2AS with the 18 bacterial and 4 sulmon DNAs tested, the PCR produced a product only with the 5 isolates of Piscirickettsia salmonis (Fig. 1). PCR performed with the $P$ salmonis-specific primers did not produce products when Neorickettsia/Nanophyetus DNA from infected kidney tissues or concentrated metacercaria were used as templates (Fig. 5).

The nested assay distinguished between Piscirickettsia salmonis when compared with other bacteria including 12 species of fish pathogens, and no products were produced from the DNA from the 4 species of salmon examined (Fig. 1). When using PS2S and PS3AS as primers, a product was produced with all isolates of $P$. salmonis examined except EM-90. Amplification using PS2S and EM90AS produced a product only with isolate EM-90 (Fig. 2).

\section{Amplification from infected tissue}

With a single amplification of the infected fish tissue, using the P. salmonis-specific primers, $50 \%$ of the reactions produced the expected product (gel not shown). All tissue infected with $P$. salmonis revealed the expected 467 bp product when the nested PCR amplification was performed (Fig. 6). Close examination of the gel was required to observe the bands in lanes 4 and 5 and they could easily have been improperly identified as negative. The 467 bp band was not observed in any of the non-infected tissue or the preparations containing no DNA.

\section{DISCUSSION}

The PCR has shown potential for improving the diagnosis of infectious diseases caused by fastidious or slowly growing microorganisms (Eisenstein 1990). PCR assays have been used for the detection of a number of other rickettseae, i.e. Coxiella burnetii (Mallavia et al. 1990), Rickettsia rickettsii (Tzianabos et al. 1989), and Rickettsia typhi (Carl et al. 1990).

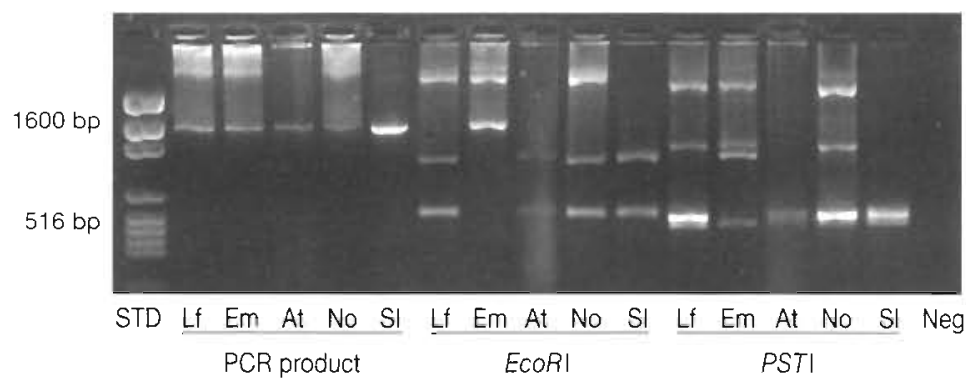

Fig. 4. PCR-RFLP patterns of $16 \mathrm{~S}$ rDNA from Piscirickettsia salmonis isolates digested with EcoRI or PSTI Lf $=$ LF-89, Em = EM-90, A.t = ATL-4 91, No $=$ NOR-92, S1 = SLGO-94. The 16S rDNA genes for isolates LF-89, EM-90 and NOR-92 were amplified from inserts in the pCRII plasmid. $S T D=$ pGEM DNA markers. Neg = no DNA negative control 


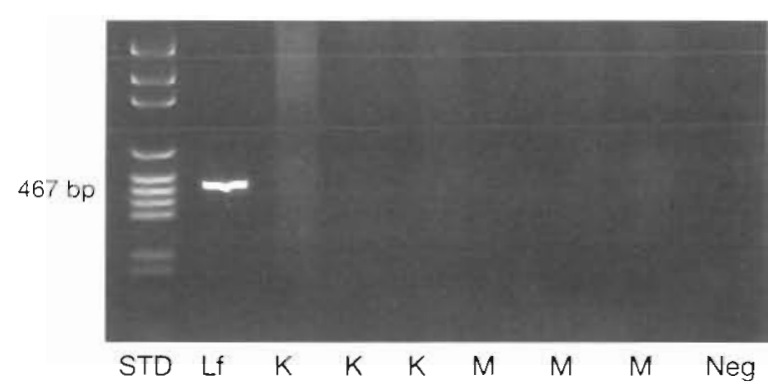

Fig. 5. Specificity of Piscirickettsia salmonıs PCR using DNA from adult steelhead trout Oncorhynchus mykiss kidney tissue infected with Nanophyetus salmonicola metacercaride the host for Neorickcttsia helmintheoca. Lanes marked K use infected kidney tissue. Lanes marked $M$ use DNA from concentrated metacercaria. The metacercaria averaged $6.8 \times 10^{5}$ per gram of kidney ticsile STD) = pGEM DNA markers (Pro mega). Lf $=$ LF -89 positive control. Neg = no DNA negative control

Here we have described the development of PCR assays for the detection of Piscirickettsia salmonis DNA in fish cell cultures and tissues of infected fish. Amplification using the primer pair PS2S-PS2AS can distinguish $P$. salmonis from its fish host and other bacteria. The PCR assays using PS2S and either PS3AS and EM90AS distinguished between EM-90 and the other isolates of $P$. salmonis. The nested PCR was more sensitive and reliable than 2 sequential amplifications using the $P$. salmonis-specific primers.

The nested PCR approach increased the sensitivity of the assay from $60 \mathrm{TCID}_{50}$ to less than. $1 \mathrm{TCID}_{50}$. which should allow detection early in the infection when the quantity of bacteria in the tissue is low. The variation in the amount of product produced with the nested PCR is due to the variation in the quantity of Piscirickettsia salmonis in the infected tissue. Therefore, replicate amplifications are recommended to confirm negative results. One $\mathrm{TCID}_{50}$ may represent infection with more than 1 bacterial cell leading to an underestimate of the number of $P$. salmonis cells present. Therefore, the detection of less than 1 TCID $_{50}$ does not mean that less than 1 P. sal-

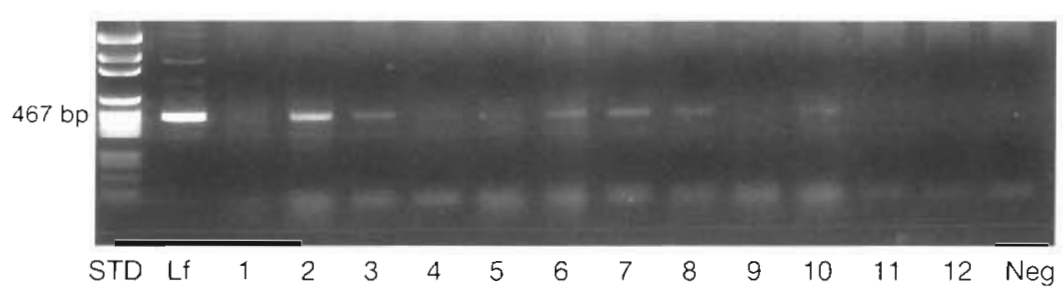

Fig. 6. Agarous gel electrophoresis of Piscirickettsıa salmonis-specific nested PCR using infected fish tissue. Lanes $2-8,10$ were $P$. salmonis positive fish tissue samples. Lanes 1, 9, 11, 12 were $P$. salmonis negative fish tissue samples. $467 \mathrm{bp}$ indicates the expected PCR product. STD = pGEM DNA markers. Neg $=$ no DNA negative control monis bacterium can be detected; instead it probably reflects the affinity of $P$. salmonis to host cell membranes, which leads to clumping. DNA from nonviable $P$. salmonis bacterial cells will be present in the preparation, further complicating the quantification of the number of infectious bacterial cells represented by the DNA preparation. We attempted to overcome this by measuring the TCID 50 , staining the cells with Giemsa and counting by haemocytometer. The numbers agreed within $15 \%$ between the 2 methods.

Currently, preliminary diagnosis of Piscirickettsia salmonis relies on the presence of gross signs of disease and Giemsa staining of infected fish tissue, with confirmation by IFAT (Lannan et al. 1991). However, $P$. saimonis infections which are in the early stages when few bacterial cells are present or from fish which are asymptomatic carriers could go undetected by these tests. The sensitivity of the nested PCR assay will allow identification of the infectious agent below the detection limits of microscopic examination. Using the nested. PCR will also allow the tissue distribution of the bacterium to be studied early in the infection prior to the onset of disease signs, thus resulting in a better understanding of the transmission and pathogenesis of $P$. salmonis.

The entire process of tissue preparation, DNA isolation, amplification and visualization of the PCR products can be accomplished in 1 to $2 \mathrm{~d}$. The PCR/RFLP procedures take considerable less time than culturing Piscirickettsial agents and can differentiate between strains which cannot be distinguished by polyclonal IFAT.

A number of rickettsia-like bacteria have been recently observed in a variety tish hosts (Chern \& Chao 1994, Khoo et al. 1995, Wada et al. 1995, Comps 1996). The discovery of these agents makes it likely that Pisciricketisia salmonis is only the first aquatic rickettsia-like bacterium to be characterized. Using the nested PCR assay described here will allow $P$. salmonis to be rapidly distinguished from the other agents and help in understanding the classification of this emerging group of microorganisms.

The PCR methods presented here are rapid, sensitive and specific tests for Piscirickettsia salmonis and will be useful in defining the biology, taxonomy and ecological characteristics of this agent. The sensitivity and specificity of these PCR procedures will be useful for defining the mode(s) of transmission, the natural host(s), the reservoir(s), and the geographical distribution of $P$. salmonis and other related rickettsia-like organisms. 
Acknowledgements. The authors thank P. Caswell-Reno and M. Whipple (Hatfield Marine Science Center, Oregon State University) for maintaining the Piscirickettsia salmonis cultures. We also thank E. Madrid IMarine Harvest, Puerto Montt, Chile), P. Smith (University of Chile, Santiago, Chile), G. Traxler (Pacific Biolagical Station, Nanaimo, BC) and H. P. Melby (National Veterinary Institute, Oslo, Norway) for providing $P$. salmonis isolates EM-90, SLGO-94, ATL-4-92 and NOR-91 respectively. We thank Dr Tony Amandi and Craig Banner (Oregon Department of Fish and Wildlife), Dan Mourich, Dr J. Leong, and Doug Gordon (Department of Microbiology, Oregon State University) for their comments and advice. This work was supported by Sea grant no. NA36RG0451. This is Oregon Agricultural Experiment Station technical paper no. 1.2878

\section{LITERATURE CITED}

Bravo S, Campos M (1989) Coho salmon syndrome in Chile. AFS Fish Health Section Newsletter 17(3):3

Carl M. Tibbs MCW, Dobson ME, Paperello S, Dasch GA (1990) Diagnosis of acute typhus infection using the polymerase chain reaction. J Infect Dis 161:791-193

Chein RS, Chao CB (1994) Outbreaks of a disease caused by rickettsia-like organism in cultured tilapias in Taiwan. Fish Pathol 29(2):61-71

Comps M. Raymond JC, Plassiart GN (1996) Rickettsia-like organism infecting juverile sea-bass Dicentrarchus labrax. Bull Eur Ass Fish Pathol 16:30-33

Eisenstein Bl (1990) The polymerase chain reaction. A new method of using molecular genetics for medical diagnostics. N Engl J Med 323:178-183

Evelyn TPT (1992) Salmonid rickettsial septicemia. In: Kent $\mathrm{ML}$ (ed) Diseases of seawater netpen-reared salmonid fishes in the Pacific Northwest. Can Spec Pub Fish Aquat Sci 116:18-19

Fryer JL, Lannan CN, Garces LH, Larenas JJ, Smith PA (1990) lsolation of a rickettsiales-like organism from diseased coho salmon (Onchorhyncus kisutch) in Chile. Fish Pathol 25:107-114

Responsible Subject Editor: D. W. Bruno, Aberdeen, Scotland, UK
Fryer JL, Lannan CN, Giovannoni SJ, Wood ND (1992) Piscirickettsia salmonis gen. nov., sp. nov, the causative agent of an epizootic disease in salmonid fishes. Int $J$ Syst Bacteriol 42(1):120-126

Gebhardt GA, Millemann RE, Knapp SE, Nyberg PA (1966) 'Salmon poisoning' disease. Vol. II. Second intermediate host studies. J Parasitol 52:54-59

Giovannoni S (1991) The polymerase chain reaction. In: Stackebrandt E, Goodfellow M (eds) Nucleic acid techniques in bacterial systematics. John Wiley and Sons, New York, p 177-201

Khoo L, Dennis LPM, Lewbart GA (1995) Rickettsia-like organisms in the blue-eyed plecostomus, Panaque suttoni (Eigenmann and Eigenmann). J Fish Dis 18:157-164

Lannan CN, Ewing SA, Fryer JL (1991) A fluorescent antibody test for the detection of the rickettsia causing disease in Chilean salmonids. J Aquat Anim Health 3:229-234

Lannan CN, Winton JR, Fryer JL (1984) Fish cell lines: establishment and characterization of nine cell lines from salmonids. In Vitro 20:671-676

Maidak BL, Larsen N, McCaughey MJ, Overbeek R, Olsen GJ, Fogel K, Blandy J, Woese CR (1994) The Ribosomal Data Base project. Nucleic Acid Res 22(17):3485-3487

Mallavia LP, Whiting LL, Minnick MF, Heinsen R, Reschke D, Foreman M, Baca OG, Frazier ME (1990) Strategy for detection and differentiation of Coxiella burnetii strains using the polymerase chain reaction. Ann NY Acad SCl 590:572-581

Olsen AB, Evensen O, Speilberg L, Melby HP, Hansen T (1993) 'NY' laksesykdom forarsaket av rickettsie. Nor Fiskeoppdrett NR 12:40-41

Rodger HD, Drinan EM (1993) Observation of a rickettsia-like organism in Atlantic salmon, Salmo salar L., in Ireland. $J$ Fish Dis 16:361-369

Tzianabos T, Anderson BE, MicDade JE (1989) Detection of Rickettsia rickettsii DNA in clinıcal specimens by using the polymerase chain reaction technology. J Clin Microbiol 27:2866-2868

Wada S, Hatai K, Shimotsu $T$ (1995) A disease with liver swelling and nodule formation in cultured tilapia. 1995 Spring Meeting Jap Soc Fish Pathol, Tokyo (abstract in Japanese)

Manuscript first received: January 5, 1996

Revised version accepted: April 19, 1996 